\title{
Some Effects in vivo of the Teat Canal and Effects in vitro of Cationic Proteins on Staphylococci
}

\author{
By K. G. HIBBITT AND MARGARET BENIANS \\ Department of Biochemistry, Institute for Research on Animal Diseases, \\ Compton, Newbury, Berkshire
}

(Accepted for publication 5 July 197I)

SUMMARY

Staphylococci incubated with calf thymus histone F $2 \mathrm{~A}$ or teat canal cationic protein bound more ${ }^{131}$ I bovine serum albumin than untreated bacteria. In experiments in vivo a similar increased binding of labelled albumin was observed in bacteria deposited in the teat canal of the cow and recovered $24 \mathrm{~h}$. later. Antimicrobial cationic proteins may become attached to the surface of bacteria deposited in the teat canal. Incubation of staphylococci, containing ${ }^{14} \mathrm{C}$-labelled protoplasmic proteins, in isotonic saline with calf thymus histone F $2 \mathrm{~A}$ or teat canal cationic proteins caused a rapid release of the labelled protein followed by a slower release which continued for $5 \mathrm{~h}$. Bovine serum albumin induced no greater protein leakage than isotonic saline.

\section{INTRODUCTION}

Cationic proteins have an antimicrobial effect on a number of bacteria, including Escherichia coli, Salmonella typhimurium, Pseudomonas aeruginosa, Klebsiella pneumoniae, streptococci and staphylococci (Hirsch, 1958; Zeya \& Spitznagel, I966; Hibbitt, Cole \& Reiter, 1969). In vitro, these proteins bind electrovalently to the surface of staphylococci (Hibbitt, Brownlie \& Cole, I97I) and, after incubation at $37^{\circ}$, produce considerable morphological changes consisting of damage to the cell wall and plasma membrane (MacMillan \& Hibbitt, 1969) which could lead to a leakage of protoplasmic contents. These effects were produced by proteins isolated from the teat canal keratin of the cow and by calf thymus histone F 2 A. Similar changes in fine structure were observed in staphylococci deposited within the teat canal of a healthy cow and recovered $24 \mathrm{~h}$. later, which may indicate a reaction of the host to the deposited pathogens.

In this study an attempt has been made to explore some of the possible effects the teat canal cationic proteins may have on invading micro-organisms. The possibility that these proteins bind to the staphylococcal surface was studied in vivo in the teat canal by comparing the ability of recovered bacteria and untreated control bacteria to bind ${ }^{131} \mathrm{I}$-labelled bovine serum albumin; the anionic albumin would be held more firmly by a positively charged protein coat than by the untreated wall. The rate of release in vitro of ${ }^{14} \mathrm{C}$-labelled protoplasmic proteins during incubation with cationic proteins was also studied.

\section{METHODS}

Organisms. A bovine pathogenic strain of Staphylococcus aureus was used in all experiments. This organism was isolated from a case of bovine mastitis and is penicillin sensitive, coagulase positive to sheep and rabbit plasma and has the following phage typing: $52 / 52 \mathrm{~A} /$ 79/42 E/53/77/83 A/42 D. 
Animals. The experiments involving the deposition of staphylococci into teat canals $24 \mathrm{~h}$. before slaughter of the cows were carried out on Ayrshire and Friesian cows of the Institute herd. Cows were selected for the experiments only if they had received no antibiotic treatment during the previous three months and were known to have been free from clinical mastitis for at least two years.

Procedure for the injection of staphylococci into the teat canal. Staphylococcus aureus were grown overnight in $300 \mathrm{ml}$. of nutrient broth (Oxoid no. 2, CM67) and centrifuged at $2000 \mathrm{~g}$ for $20 \mathrm{~min}$. The sedimented bacteria were washed in isotonic saline, recentrifuged, and resuspended in $1.0 \mathrm{ml}$. sterile milk. Each teat canal was injected with $0.0 \mathrm{I} \mathrm{ml}$. of the suspension using a $4.0 \mathrm{~mm}$. needle, as described previously (Hibbitt \& Jones, 1967). Immediately after the deposition of the staphylococci in the teat canals total and viable counts were made on the staphylococcal suspension remaining in the syringe. The total number of staphylococci injected into each teat canal varied between $6 \times 10^{8}$ and $5.8 \times 10^{9}$. The viability of the bacteria varied from $40 \%$ to $100 \%$ depending on the exact duration of the overnight incubation.

Recovery of bacteria from the teat canals. The teats were removed from the cows at slaughter, washed in running tap water and dried in sterile, absorbent cotton-wool. The teat canals were opened with a scalpel and the bacteria recovered from the exposed canal by three successive washings with a total of $10.0 \mathrm{ml}$. sterile saline delivered from a sterile syringe through a 20-gauge needle. The collected washings from four teats were filtered through a thick pad of glass wool to remove any large particles of keratin. Total counts of the bacteria recovered from each cow were determined on suitable dilutions of the washings in a Helber counting chamber (Hawksley, Lancing, Sussex) under an interference microscope.

Labelling of bovine serum albumin with ${ }^{131}$ I. Bovine serum albumin (BSA) was labelled with batches of carrier-free ${ }^{131} \mathrm{I}$, obtained from the Radiochemical Centre, Amersham, Buckinghamshire, as described by Hunter \& Greenwood (I962). The labelled protein was passed down a G 50 Sephadex column and collected into a solution of $2.5 \mathrm{mg}$. carrier BSA in $0.145 \mathrm{M}$-saline buffered with $0.5 \mathrm{M}$-sodium phosphate at $\mathrm{pH} 7.5$. The solutions of labelled protein (mean volume $4.7 \mathrm{ml}$.) obtained had a mean specific activity of $0.21 \mu \mathrm{Ci} / \mathrm{ml}$.

The binding of $\left[{ }^{131} I\right] B S A$ to the recovered bacteria. The suspension of recovered organisms was centrifuged and the pellet resuspended in $0.25 \mathrm{ml}$. [ $\left.{ }^{131} \mathrm{I}\right] \mathrm{BSA}(0.2 \mathrm{I} \mu \mathrm{Ci} / \mathrm{ml}$.) and incubated for $30 \mathrm{~min}$. at room temperature with gentle shaking. Similar numbers of staphylococci to the recovered micro-organisms were incubated with [ $\left.{ }^{131} \mathrm{I}\right] \mathrm{BSA}$ under exactly the same conditions in the control experiments. Isotonic saline ( $1 \cdot 0 \mathrm{ml}$.) was added to the 'recovered' and 'control' mixtures at the end of the incubation; these were then washed through a $0.5 \mu \mathrm{m}$. Millipore filter with $5^{\circ} \mathrm{O} \mathrm{ml}$. sterile isotonic saline. This washing was followed by four $5 \mathrm{ml}$. portions of sterile isotonic saline. The filters retaining the bacteria were removed and placed directly into counting pots and counted in a $\gamma$ scintillation counter with a $\mathrm{NaI}$ well crystal. All the Millipore filters used were presoaked overnight in isotonic saline containing $20 \mathrm{mg} . / \mathrm{ml}$. BSA to reduce the absorption of [ $\left.{ }^{131} \mathrm{I}\right] \mathrm{BSA}$. As this presaturation with albumin was only partly effective in preventing the binding of labelled BSA to the filter, a saturated control filter through which was washed $0.25 \mathrm{ml}$. of the [ $\left.{ }^{131} \mathrm{I}\right] \mathrm{BSA}$ solution was counted to correct errors due to the absorption of labelled albumin. The background activity was measured on a Millipore filter saturated with BSA.

The binding of $\left[{ }^{131} I\right] B S A$ to staphylococci incubated with cationic proteins. A $300 \mathrm{ml}$. overnight culture of Staphylococcus aureus in nutrient broth was divided and each half centrifuged at $2000 \mathrm{~g}$ for $20 \mathrm{~min}$. The supernatant solutions were poured off and one pellet was resuspended in $5.0 \mathrm{ml}$. isotonic saline containing $250 \mu \mathrm{g}$. calf thymus histone $\mathrm{F} 2 \mathrm{~A}$ 
(Sigma Chemical Company, London) or teat canal cationic proteins (Hibbitt, Cole \& Reiter, 1969)/ml. and the other pellet was suspended in $5 \mathrm{ml}$. isotonic saline alone. Both suspensions were incubated for $\mathrm{I} \mathrm{h}$. at $37^{\circ}$ and then centrifuged at $2000 \mathrm{~g}$ for $15 \mathrm{~min}$. The pellets were washed once by resuspending in isotonic saline. The washed pellets were suspended in $0.25 \mathrm{ml}$. $\left.{ }^{[31} \mathrm{I}\right] \mathrm{BSA}$ and incubated for $30 \mathrm{~min}$. at room temperature. The incubated staphylococci were filtered, washed and counted in the scintillation counter as described above.

Labelling of staphylococci with $\left[\mathrm{I}^{14} \mathrm{C}\right]$ valine. Staphylococcus aureus was grown in $5.0 \mathrm{ml}$. Oxoid nutrient broth containing $0.05 \mathrm{mCi}$ of $\left[\mathrm{I}-{ }^{14} \mathrm{C}\right]$ valine. The culture was incubated at $37^{\circ}$ for $\mathrm{I} 6 \mathrm{~h}$. and then sedimented at $2000 \mathrm{~g}$ for $\mathrm{I} 5 \mathrm{~min}$. The supernatant was poured off and the pellet washed twice in $5^{\circ} \mathrm{Oml}$. volumes of sterile isotonic saline. The final pellet of ${ }^{14} \mathrm{C}$-labelled staphylococci was resuspended in $5^{\circ} 0 \mathrm{ml}$. isotonic saline.

The leakage of labelled protein from the staphylococci. The $5^{\circ} 0 \mathrm{ml}$. suspension of labelled staphylococci was thoroughly mixed, divided, and one $2.5 \mathrm{ml}$. portion centrifuged at $2000 \mathrm{~g}$ for $15 \mathrm{~min}$. The sedimented bacteria were resuspended in a further $2.5 \mathrm{ml}$. isotonic saline solution containing $250 \mu \mathrm{g}$. of the protein under investigation (teat canal cationic proteins, calf thymus histone F 2 A or bovine serum albumin) $/ \mathrm{ml}$. Both suspensions of labelled staphylococci were incubated at $37^{\circ}$ for up to $5 \mathrm{~h}$. in a water bath with gentle shaking. Samples $(0.2 \mathrm{ml}$.) were withdrawn from the thoroughly mixed control and test suspensions at $10,20,30$ and $60 \mathrm{~min}$. and then at $2,3,4$ and $5 \mathrm{~h}$. The samples were pipetted into $0.5 \mathrm{ml}$. isotonic saline in conical centrifuge tubes and after mixing were centrifuged at $2000 \mathrm{~g}$ for Io min. A $0.4 \mathrm{ml}$. portion was carefully removed from the top of the supernatant without disturbing the pellet and added to $0.5 \mathrm{ml} .25 \%(\mathrm{w} / \mathrm{v})$ trichloroacetic acid in another conical centrifuge tube; after mixing and standing for $15 \mathrm{~min}$. the precipitated protein was sedimented at $2000 \mathrm{~g}$ for $\mathrm{I} 5 \mathrm{~min}$., washed by resuspending in $5 \%(\mathrm{w} / \mathrm{v})$ trichloroacetic acid and resedimented. The supernatant was poured off and the pellet allowed to drain before being solubilized with $0.5 \mathrm{ml}$. $0 . \mathrm{I} \mathrm{N}-\mathrm{NaOH}$. A $0.2 \mathrm{ml}$. portion was added to Io ml. scintillation fluid which contained $5 \mathrm{~g}$. of 2,5-diphenyloxazole, $50 \mathrm{mg}$. 1,4-bis(5-phenyloxazol-2-yl)benzene and $80 \mathrm{mg}$. naphthalene/l. of a toluene-dioxan-ethanol mixture $(5: 5: 3)$. The samples were counted in a scintillation counter (Beckman Instruments, Glenrothes, Fife) for $10 \mathrm{~min}$. or until all values were within a $5 \%$ error.

\section{RESULTS}

The binding of $\left[{ }^{131} I\right] B S A$ to staphylococci incubated with cationic proteins. Staphyl ococc incubated with calf thymus histone $\mathrm{F} 2 \mathrm{~A}$ bound considerably more [ $\left.{ }^{131} \mathrm{I}\right] \mathrm{BSA}$ than untreated control bacteria; they also did so treated with the cationic proteins isolated from the teat canal keratin. The results of these four experiments are shown in Table $\mathrm{I}$; they show variation, but the ratio of the protein binding to the treated bacteria to that binding to control bacteria did not fall below $6: \mathrm{I}$.

The binding of $\left.{ }^{131} I\right] B S A$ to the bacteria recovered from the teat canal of the cow. Labelled BSA bound more readily to the bacteria recovered from the teat canal of the cow than to the control bacteria. The results of these experiments in vivo which are shown in Table 2 resemble the results of the experiments in vitro (Table I), but the recovered bacteria bound the albumin more readily since in all the cows studied the ratio of the protein binding to the recovered bacteria to that binding to control bacteria exceeded 22: $\mathrm{I}$. The labelled BSA was firmly bound to the staphylococci both in vitro and in vivo. Repeated washing with isotonic saline (O. I $45 \mathrm{M})$ did not reduce the radioactivity of the organisms. Furthermore, labelled albumin was not removed even when the staphylococci were washed in $3.0 \mathrm{M}-\mathrm{NaCl}$. 


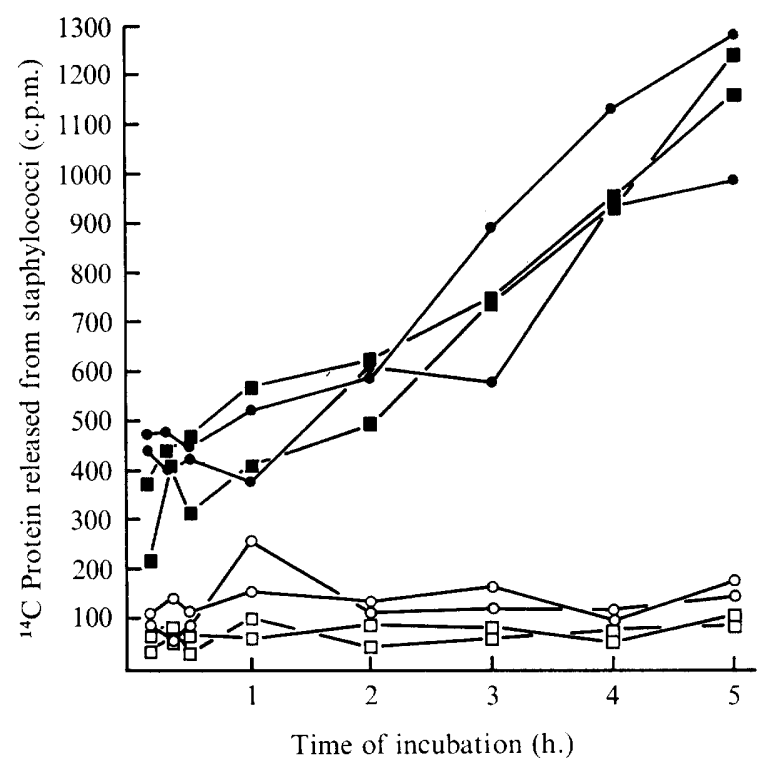

Fig. I. Duplicate experiments showing the release of ${ }^{14} \mathrm{C}$-labelled protoplasmic proteins from staphylococci incubated with: calf thymus histone F2 A (O-

$(\square-\square)$; bovine serum albumin $(\mathrm{-}-\mathrm{O})$; isotonic saline $(\square-\square)$.

Table I. The binding of ${ }^{131}$ I bovine serum albumin to staphylococci previously incubated with cationic proteins

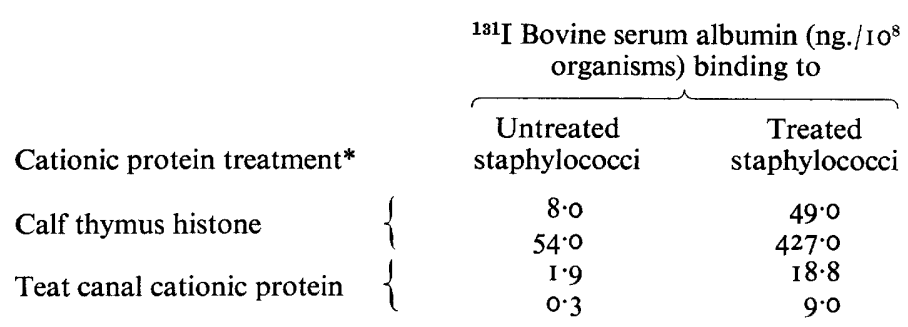

* Staphylococci were incubated for I h. at $37^{\circ}$ in isotonic saline containing $250 \mu \mathrm{g} . / \mathrm{ml}$. calf thymus histone $\mathrm{F} 2 \mathrm{~A}$ or teat canal cationic proteins. The bacteria were washed in isotonic saline to remove the unbound protein.

Table 2. The binding of ${ }^{131}$ I bovine serum albumin to bacteria recovered from the teat canal of the cow

\begin{tabular}{ccc} 
Cow no. & $\begin{array}{c}{ }^{131} \text { I Bovine serum albumin (ng./10 } \\
\text { bacteria) binding to }\end{array}$ \\
\cline { 2 - 2 } $\begin{array}{c}\text { Untreated } \\
\text { bacteria }\end{array}$ & $\begin{array}{c}\text { Recovered } \\
\text { bacteria }\end{array}$ \\
2 & $7 \cdot 9$ & $423 \cdot 0$ \\
3 & $7 \cdot 7$ & $207 \cdot 0$ \\
4 & 0.0 & $272 \cdot 0$ \\
5 & $75 \cdot 0$ & $1694 \cdot 0$ \\
& 0.0 & $802 \cdot 0$
\end{tabular}


The release of $\left[\mathrm{I}^{14} \mathrm{C}\right]$ valine-labelled protoplasmic proteins from staphylococci. Cationic proteins isolated from the teat canal of the cow have an antimicrobial action on staphylococci (Hibbitt, Cole \& Reiter, I969). The addition of teat canal cationic proteins to staphylococci, containing ${ }^{14} \mathrm{C}$-labelled protoplasmic proteins, suspended in isotonic saline induced a rapid release of the bacterial protoplasm (Fig. I). This effect on the staphylococci was not restricted to the teat canal proteins alone since a very similar release of labelled protein was produced by calf thymus histone fraction $\mathrm{F} 2 \mathrm{~A}$. The labelled protein appeared to be released from the staphylococci in two phases by both cationic proteins. A rapid loss of protein occurred during the first 10 to $20 \mathrm{~min}$. This phase was followed by a steadier release of radioactivity until the end of the $5 \mathrm{~h}$. incubation. The first phase may have been due to an initial rapid increase in plasma membrane permeability, allowing a release of soluble protein of low molecular weight, while the second phase may have been associated with an increased osmotic fragility of the staphylococci due to wall damage. The effect of bovine serum albumin at the same concentration in isotonic saline was not significantly different from that of the untreated saline controls (Fig. I).

\section{DISCUSSION}

The change in membrane permeability associated with cationic proteins is not restricted to micro-organisms. Drew \& McLaren (1970) demonstrated a changed permeability in the membranes of barley roots treated with various polycations, and Ryser \& Hancock (1965) showed that crude calf thymus histone in concentrations of $100 \mu \mathrm{g} . / \mathrm{ml}$. changed the permeability of sarcoma S I 80 cells to permit an uptake of albumin I 5 times that of the untreated controls in I h. Similar changes of permeability were also demonstrated by Ryser (1967) using basic polyamino acids. It was suggested by these workers that the cationic proteins may produce a molecular rearrangement of the cell membrane or stimulate pinocytosis. A direct comparison between staphylococci and sarcoma cells in culture would not be possible, but in the present study the [ $\left.{ }^{131} I\right] \mathrm{BSA}$ appeared to bind very firmly to some part of the bacterial cell as a consequence of the prior treatment with cationic proteins. This may suggest more than a simple binding of protein to the surface of the cells.

The naturally occurring cationic proteins may fulfil the role not only of providing the host with an initial natural line of defence, but of helping to render the pathogen more susceptible to the action of immune globulins.

The authors are grateful for the help provided by $\mathrm{Mr} \mathrm{N}$. Elcock in the selection of suitable animals for the experiments and for the technical assistance of Miss B. Hewitt.

\section{REFERENCES}

Drew, M. \& MCLAREN, S. (1970). The effect of histones and other basic macromolecules on cell permeability and elongation of barley roots. Physiologia Plantarum 23, 544-560.

Hibbitt, K. G., Brownlie, J. \& Cole, C. B. (I97I). The antimicrobial activity of cationic proteins isolated from the cells in bulk milk samples. Journal of Hygiene, Cambridge 69, 6I-68.

Hibiitt, K. G., Cole, C. B. \& Reiter, B. (I969). Antimicrobial proteins isolated from the teat canal of the cow. Journal of General Microbiology 56, 365-37I.

HiвBITT, K. G. \& JoNES, G. W. (1967). Quantitative deposition of bacteria within the teat canal of the goat. Veterinary Record 80, 270-272.

HiRSCH, J. G. (1958). Bactericidal action of histone. Journal of Experimental Medicine 1o8, 925-944.

Hunter, W. M. \& Greenwood, F. C. (1962). Preparation of iodine-I3I labelled human growth hormone of high specific activity. Nature, London 194, 495-496.

MacMillan, W. G. \& HibBitT, K. G. (1969). The effect of antimicrobial proteins on the fine structure of Staphylococcus aureus. Journal of General Microbiology 56, 373-377. 
RYSER, H. J.-P. \& HANCOCK, R. (1965). Histones and basic polyamino acids stimulate the uptake of albumin by tumor cells in culture. Science, New York 150, 50I-503.

RYSER, H. J.-P. (1967). A membrane effect of basic polymers dependent on molecular size. Nature, London 215, 934-936.

Zeya, H. I. \& SpitznaGel, J. G. (1966). Cationic proteins of polymorphonuclear leukocyte lysosomes. Journal of Bacteriology 9I, 750-754. 